\title{
Absent F-waves in conus medullaris stroke mimicking Guillain-Barré syndrome
}

\author{
Hyun Hor, ${ }^{1,2}$ Husain Nader, ${ }^{3}$ Alexander Andrea Tarnutzer ${ }^{1,2}$
}

${ }^{1}$ Neurology, University Hospital Zurich, Zurich, Switzerland ${ }^{2}$ Faculty of Medicine, University of Zurich, Zurich, ZH,

Switzerland

${ }^{3}$ Institute of Neuroradiology, University Hospital Zurich, Zurich, Switzerland

Correspondence to Dr Alexander Andrea Tarnutzer, atarnutzer@gmail.com

Accepted 4 November 2018

\section{DESCRIPTION}

A 51-year-old female patient presented to the emergency room with sudden-onset weakness and pain in both legs, urinary retention, as well as loss of sensation in the genitourinary area. The symptoms appeared after bending forward and worsened over 3 hours. Initial neurological examination revealed incomplete left-dominant proximal and distal flaccid paraparesis, reduced tendon reflexes (right patellar jerk and both ankle jerk reflexes), reduced sphincter tone and incomplete sensory loss below Th12 consisting mainly of reduced sensation to light touch, pin prick and pain in both legs and in the genitourinary area. In contrast, both strength and sensation were normal in the arms. Given a normal spinal MRI and lumbar puncture on admission day, electroneurography was ordered. Whereas motor and sensory conduction velocities were normal, F-waves for both peroneal and tibial of early-stage Guillain-Barré syndrome was made, and the patient was treated with intravenous immunoglobulins (IVIG) for 5 days, with only a weak response. Spinal MRI was therefore repeated on day 7 , now showing a swelling of the conus medullaris and an increased signal of the anterior horn on

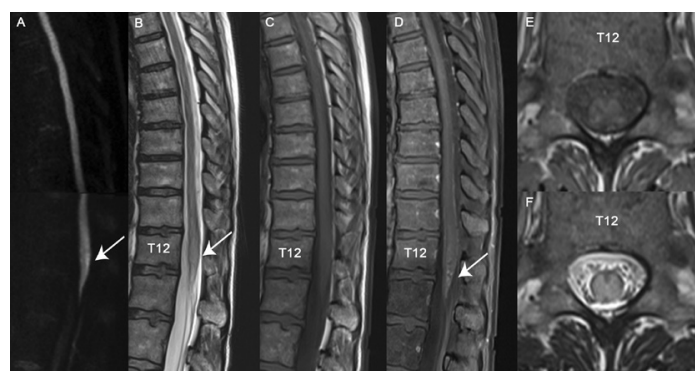

BMJ Publishing Group Limited 2018. No commercial re-use. See rights and permissions. Published by BMJ.

To cite: Hor $\mathrm{H}$, Nader $\mathrm{H}$, Tarnutzer AA. BMJ Case Rep 2018;11:e227726 doi:10.1136/bcr-2018227726

Figure 1 Sagittal (A-D) and axial (E-F) spinal MRI (day 7). Restricted diffusion on diffusion-weighted imaging ( $A$, arrow), swelling and $T 2$-hyperintensity ( $B$, arrow) and contrast enhancement ( $D$, arrow) compared with native T1 (C) in the conus medullaris are shown. At T12 level, the conus medullaris demonstrates focal contrastnerves on day 2 were absent. Thus, the diagnosis

T2-weighted imaging, indicating an acute ischaemic stroke (figure 1). Retrospectively, this increase in the anterior horn signal could also be depicted on the initial MRI on the admission day.

This case emphasises that, while typically associated with acute demyelinating polyneuropathy, absent F-waves can also be indicative of conus medullaris stroke, ${ }^{1}$ and that early spinal cord MRI may be falsely negative. ${ }^{2}$ Therefore, repeated MRI should be enforced in case of lacking response to IVIG treatment in suspected Guillain-Barré syndrome.

\section{Learning points}

- Sudden-onset weakness in the legs, urinary retention and loss of sensation in the genitourinary area require an immediate diagnostic workup.

- Key diagnostic testing includes spinal MRI, lumbar puncture and electroneurography.

- While early spinal cord MRI may be falsely negative, absent F-waves are non-specific and may also be indicative of conus medullaris stroke.

Contributors AAT: drafting of manuscript and analysis/

interpretation of general neurological findings and ENMG-findings. $\mathrm{HyH}$ : analysis and interpretation of clinical findings, critical revision of the manuscript for important intellectual content. HuN: analysis and interpretation of MR images.

Funding The authors have not declared a specific grant for this research from any funding agency in the public, commercial or not-for-profit sectors.

Competing interests None declared.

Patient consent Obtained.

Provenance and peer review Not commissioned; externally peer reviewed. enhancement $(E, T 1)$ and swelling $(F, T 2)$. 
Copyright 2018 BMJ Publishing Group. All rights reserved. For permission to reuse any of this content visit https://www.bmj.com/company/products-services/rights-and-licensing/permissions/

BMJ Case Report Fellows may re-use this article for personal use and teaching without any further permission.

Become a Fellow of BMJ Case Reports today and you can:

- Submit as many cases as you like

- Enjoy fast sympathetic peer review and rapid publication of accepted articles

Access all the published articles

- Re-use any of the published material for personal use and teaching without further permission

For information on Institutional Fellowships contact consortiasales@bmjgroup.com

Visit casereports.bmj.com for more articles like this and to become a Fellow 